JURNAL ILMIAH MUQODDIMAH

Jurnal IImu Sosial, Politik, dan Humaniora

\title{
EVALUASI PERAN WALI PEMASYARAKATAN DALAM PELAKSANAAN ADMISI ORIENTASI BAGI NARAPIDANA (Studi Kasus di Lembaga Pemasyarakatan Kelas IIA Jambi)
}

\author{
Ilham Kurniadi ${ }^{1}$, Cindana Wijayanti ${ }^{2}$ \\ Politeknik IImu Pemasyarakatan \\ Universitas Bina Darma ${ }^{2}$ \\ ilhamkurniadii@gmail.com ${ }^{1}$ \\ cindanawjynti@gmail.com²
}

\begin{abstract}
Abstrak
Tujuan yang lebih penting terhadap pemidanaan seseorang yang terbukti melanggar hukum adalah untuk memperbaiki dan membina pelaku tindak pidana sehingga dapat kembali ke masyarakat dan menjadi masyarakat yang baik dan berguna. Dalam pembinaan terhadap narapidana didampingi oleh petugas pemasyarakatan yang dinamakan wali pemasyarakatan. Tulisan ini bertujuan untuk mengevaluasi peran wali pemasyarakatan dalam pelaksanaan admisi orientasi bagi narapidana di Lapas Kelas IIA Jambi. Pengumpulan data dan informasi menggunakan metode penelitian yuridis empiris melalui teknik pengumpulan data kualitatif berupa wawancara secara langsung dan studi pustaka. Hasil penelitian menunjukkan bahwa peran wali pemasyarakatan dalam pelaksanaan adimisi orientasi bagi narapidana belum terlaksana secara optimal. Hal tersebut disebabkan karena wali pemasyarakatan belum paham mengenai tugas, tanggung jawab dan kewajibannya.
\end{abstract}

Kata Kunci: admisi orientasi, narapidana, lembaga pemasyarakatan

\begin{abstract}
The more important goal of convicting someone who is proven to violate the law is to improve and foster perpetrators of crime so that they can return to society and become a good and useful society. In guiding prisoners, they are accompanied by correctional officers called prison guards. This paper aims to evaluate the role of correctional guardians in the implementation of orientation admissions for prisoners in Class IIA Prison in Jambi. Collecting data and information using empirical juridical research methods through qualitative data collection techniques in the form of direct interviews and literature studies. The results showed that the role of the correctional guardians in the implementation of orientation orientation for inmates had not been carried out optimally. That is because prison officials do not yet understand their duties, responsibilities and obligations.
\end{abstract}

Keywords: admission orientation, prisoners, correctional institutions

\section{PENDAHULUAN}

Penjatuhan pidana kepada pelanggar hukum saat ini tidak hanya bertujuan untuk menimbulkan efek jera ataupun merupakan suatu tindakan penderitaan atau pembalasan, namun juga bertujuan supaya pelanggar hukum tersebut dapat menyadari kesalahan yang telah diperbuatnya dengan dilakukan pembinaan kepadanya agar 


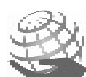

JURNAL ILMIAH MUQODDIMAH

Jurnal IImu Sosial, Politik, dan Humaniora

ia dapat kembali kemasyarakat, diterima oleh masyarakat dan berguna bagi masyarakat sekitarnya. Secara garis besar, teori pemidanaan terbagi dua dan dari penggabungan kedua teori pemidanaan tersebut lahir satu teori pemidanaan lainnya. Adapun tiga teori pemidanaan yang dijadikan alasan pembenar penjatuhan pidana :

1. Teori absolut atau teori pembalasan (vergeldings theorien),

2. Teori relatif atau teori tujuan (doeltheorien),

3. Teori gabungan (verenigingstheorien).

Sistem pemasyarakatan merupakan rangkaian sistem pemidanaan yang bertujuan agar Warga Binaan Pemasyarakatan menyadari kesalahannya, memperbaiki diri, dan tidak mengulangi tindak pidana sehingga dapat diterima kembali dilingkungan masyarakat.

Oleh karena itu, pemidanaan perlu memperhatikan sisi kemanusiaan atau perlindungan HAM (Mosgan Situmorang, 2016). Di Indonesia saat ini, proses pembinaan terhadap narapidana dilakukan didalam sebuah lembaga yang bernama Lembaga Pemasyarakatan.

Yang menjadi dasar hukum keberadaan Lembaga Pemasyarakatan di Indonesia tertuang dalam UndangUndang Nomor 12 tahun 1995 pasal 1 ayat 3, dibeutkan bahwa Lembaga Pemasyarakatan atau disingkat Lapas merupakan suatu tempat proses pembinaan bagi narapidana dan anak didik pemasyarakatan.

Dalam pelaksanakannya, Lapas memiliki suatu sitem yang dinamakan sistem pemasyarakatan sebagaimana yang tertuang dalam UU No 12 tahun 1995 pasal 1 ayat 2 yang mana maksud dari sistem tersebut ialah suatu tatanan mengenai arah, batasan dan cara pembinaan terhadap Warga Binaan Pemasyarakatan agar menyadari kesalahannya dan dapat kembali ke masyarakat serta berguna atau berperan diitengah kehidupan masarakat.
Sistem pemasyarakatan yang kita kenal saat ini merupakan suatu proses pembinaan terhadap narapidana yang berlandaskan Pancasila sebagai falsafah bangsa Indonesia dan memandang Narapidana sebagai makhluk Tuhan sebagai individu dan sekaligus sebagai anggota masyarakat dan dalam pembinaannya dapat dipulihkan dan dikembangkan kejiwaannya, jasmaninya dan mengikutsertakan narapidana secara langsung serta tidak melepaskan hubungannya dengan masyarakat diluar Lemabaga Pemasyarakatan.

Adapun beberapa artikel/jurnal terkait tentang pembinaan narapidana yakni :

1. Pelaksanaan Pembinaan

Narapidana Di Lembaga

Pemasyarakatan Kelas IIA A

Wirogunan(Studi Kasus Mary Jane) oleh Veronica Novaliana Saraswati Dewi (Dewi, 2016)

2. Optimalisasi Pelaksanaan Tugas Dan Fungsi Lapas Terbuka Dalam Proses Asimilasi Narapidana Oleh Haryno (Haryono, 2018)

Orang yang menjalani masa pidana di lembaga pemasyarakatan disebut dengan Warga Binaan Pemasyarakatan. Adapun dasar hukum tentang Warga Binaan Pemasyarakatan tertuang dalam Undang-Undang Nomor 12 tahun 1995 pasal 1 ayat 5 yang tertulis "Warga Binaan Pemasyarakatan adalah Narapidana, Anak Didik Pemasyarakatan dan Klien Pemasyarakatan".

Narapidana adalah terpidana yang menjalani pidana hilang kemerdekaan di LAPAS(Kementerian Hukum dan Hak Asasi Manusia, 1995).

Dalam sistem peradilan pidana di Indonesia saat ini, Lapas adalah satu-satunya lembaga yang berwenang sebagaitempat menjalakan putusan hakim berupa pidana penjara. Istilah pidana penjara memiliki persepsi ganda yakni sebagai salah satu jenis sanksi pidana sebagaimana diatur dalam Pasal 10 KUHP dan sebagai tempat 
JURNAL ILMIAH MUQODDIMAH

Jurnal IImu Sosial, Politik, dan Humaniora

menjalani hukuman bagi

terpidana(Aryana, 2015).

Pelaksanaan pembinaan

narapidana didalam Lembaga

Pemasyarakatan dilakukan secara

bertahap dimulai dari diterimanya

narapidana baru kedalam Lapas hingga

masa pembebasannya menjadi

anggota masyarakat seutuhnya,

termasuk pelaksanaan program-

program pembinaan yang harus dijalankan selama masa pidana. Dalam pasal 7 ayat 3 PP Nomor 31 Tahun 1999, pembinaan bagi narapidana dilaksanakan melalui 3 jenjang tahapan yaitu Tahap Awal, tahap lanjutan, dan tahap akhir. Setiap narapidana yang baru masuk menjalani masa pidana di Lapas akan mengikuti program tahap awal yang dinamakan Admisi Orientasi atau biasa disebut masa pengamatan, penelitian dan pengenalan lingkungan atau yang disingkat MAPENALING.

Pelaksanaan admisi orientasi diatur dalam pasal 10 ayat 1 PP Nomor 31 tahun 1999, dijelaskan bahwa tahap awal pembinaan diawali dengan Masa pengamatan, pengenalan \& penelitian lingkungan maksimal selama 1 bulan.

Pada tahap admisi orientasi terdapat program pembinaan yang wajib harusnya dijalani oleh narapidana yang baru masuk Lapas, dimana dalam menetapkan program pembinaan bagi narapidana dilaksanakan dengan mekanisme sidang Tim Pengamat Pemasyarakatan (TPP) dengan mempertimbangkan data-data tentang narapidana yang bersangkutan yang disampaikan oleh Wali Pemasyarakatan yang sebelumnya telah ditunjuk Kalapas untuk menjadi Wali bagi narapidana tersebut.

Pada tahapan ini diadakan penelitian dan pengamatan langsung kepada narapidana yang bersangkutan guna mengetahui latar belakang sosial (termasuk didalamnya hubungan dengan keluarga, lingkungan tempat tingal dan masyarakat sekitarnya, alasan utama penyebab narapidana tersebut melakukan kejahatan, dan segala sesuatu yang berkaitan dengan keadaan narapidana tersebut.
Berdasarkan pengamatan dan informasi yang telah didapatkan tersebut maka dapat ditentukan rencana kedepan mengenai program pembinaan yang cocok serta mengembangkan hubungan atau ikatan yang positif antara narapidana, petugas dan masyarakat.

Dalam

melaksanakan pengamatan bagi narapidana yang menjalani admisi orientasi dilakukan oleh Wali Pemasyarakatan. Berdasarkan Permenkumham RI Nomor : M01.PK.04.10. Tahun 2007 Tentang Wali Pemasyarakatan, yang dimaksud dengan Wali Pemasyarakatan adalah petugas pemasyarakatan yang melakukan pendampingan terhadap narapidana dan anak didik pemasyarakatan selama menjalani pembinaan di Lembaga Pemasyarakatan.

\section{Penunjukan}

Wali

Pemasyarakatan merupakan salah satu upaya optimalisasi pelaksanaan pembinaan narapidana dan anak didik pemasyarakatan dalam lingkungan Lembaga Pemasyarakatan. Pertimbangan ini kemudian ditindak lanjuti dengan dikeluarkannya Permenkumham Nomor

M.02.PK.04.10 Tahun 2007 Tentang Wali Pemasyarakatan dan dijabarkan lebih lanjut dalam petunjuk teknis pelaksanaan tugas perwalian narapidana dan anak didik pemasyarakatan (Surat Edaran Dirjen PAS Nomor : E.PK.04.10-90 Tanggal 12 Juli 2007), dijelaskan bahwa optimalisasi pelaksanaan pembinaan terhadap narapidana dan anak didik pemasyarakatan dalam proses pembinaan serta berinteraksi dengan petugas, sesama penghuni, dengan keluarga maupun anggota masyarakat.

Berdasarkan uraian singkat diatas, setiap narapidana yang menjalani masa admisi orientasi dilakukan pembinaan secara langsung oleh Wali Pemasyarakatan. Sehingga peran Wali Pemasyarakatan dirasa sangat penting untuk mengetahui perkembangan narapidana terkait penempatan narapidana dan program pembinaan apa saja yang cocok untuk 
JURNAL ILMIAH MUQODDIMAH

Jurnal IImu Sosial, Politik, dan Humaniora

diterapkan terhadap narapidanan yang menjalani masa admisi orientasi.

\section{Metode Penelitian \\ Pendekatan}

Pendekatan penelitian yang digunakan penulis ialah pendekatan yuridis empiris(Hadikusuma, 1995). Penelitian yang dilakukan oleh penulis bersifat deskriptif dengan menggunakan metode kualitatif, yang mana secara deskriptif penelitian akan berusaha untuk menggambarkan keadaan secara jelas, rinci dan sistematis mengenai obyek terkait yang akan diteliti(Muhammad, 2004) untuk membuktikan data yang seselektif mungkin tentang objek yang nantinya akan diteliti seperti kenyataan kondisi sebenarnya dilapangan pada saat penelitian dilakukan dan menggambarkan secara lengkap \& detail.

Penelitian deskriptif ini dilakukan guna melihat secara fakta, jelas, rinci dan sistematis mengenai implementasi pembinaan terhadap narapidana melalui program admisi orientasi di Lembaga Pemasyarakatan Kelas IIA Jambi serta guna mengetahui kesenjangan antara ketentuan-ketentuan normatif dari Permenkumham No: M.02.PK.04.10 Tahun 2007 Tentang Wali Pemasyarakatan dengan fakta keseharian di Lapas Kelas IIA Jambi.

\section{Metode Pengumpulan Data}

Metode pengumpulan data yang digunakan ialah dengan studi dokumen yang dijadikan sebagai sumber data dalam penelitian ini adalah sumber literatur, artikel, jurnal, penelitian ilmiah, dan websitet yang berkaitan dengan penelitian yang dilakukan serta dilakukan juga wawancara langsung.

Untuk melengkapi data dan informasi, maka peneliti melakukan studi lapangan (field study) secara langsung, hal ini dilakukan dengan melihat dan berkomunikasi secara langsung dengan objek kajian, narapidana yang menjalani program admisi orientasi serta petugas secara realistik pada Lembaga Pemasyarakatan Kelas IIA Jambi guna mendapatkan informasi dan fakta dilapangan secara real atau nyata.

Teknik Pemilihan Narasumber

Dalam penelitian ini, narasumber yang dipilih oleh penulis yakni melalui teknik purposive sampling dimana dalam pemilihan narasumber melalui penunjuk berdasarkan tujuan yang ingin diperoleh oleh peneliti. Narasumber dalam penelitian yang dilakukan diperoleh langsung dari Kasubsi Bimbingan Kemasyarakatan dan Perawatan, petugas pemasyarakatan yang juga sebagai wali pemasyarakatan serta naraidana yang menjalani program admisi orientasi.

\section{Teknik Analisa Data}

Data yang telah didapatkan dan dikumpulkan oleh peneliti selanjutnya dianalisis secara kualitatif dengan menggunakan uraian tata bahasa yang teratur, logis, dan efektif untuk mencapai suatu pemahaman dan pengertian untuk mengungkap suatu makna dari sudut pandang narasumber selaku pelaku yang mengalami secara langsung dan menghayati kejadian tersebut melalui pengamatan langsung oleh peneliti yang bersifat partisipatif(Moleong, 2000).

Hasil dari analisis data tersebut kemudian disimpulkan oleh penliti secara induktif yaitu suatu bentuk cara berfikir yang menarik suatu kesimpulan dari suatu pernyataan/ dalil yang bersifat khusus menjadi suatu pernyataan/ dalil yang bersifat umum.

\section{HASIL DAN PEMBAHASAN}

Sebagamanai kita ketahui saat ini, Negara Kesatuan Republik Indonesia adalah sebuah yang negara yang berlandaskan negara hukum. Dengan adanya dan diakuinya tentang konsep negara hukum sebagaimana tertuang dalam Konstitusi Negara Republik Indonesia yakni pasal 1 angka 3 Undang-Undang Dasar 1945 yang berbunyi secara tegas bahwa Negara Republik Indonesia adalah negara hukum, hal ini tentunya memiliki konsekuensi yuridis yang harus dan wajib dipertanggungjawabkan baik dalam praktik kehidupan bermasyarakat, berbangsa, maupun 
JURNAL ILMIAH MUQODDIMAH

Jurnal IImu Sosial, Politik, dan Humaniora

bernegara seperti saat ini(Yopi Gunawan and Kristian, 2015).

Pengertian

Pemasyarakatan

Lembaga

Di Indonesia saat ini, dalam penyebutan nama penjara telah dirubah menjadi suatu sebutan yang lebih manusiawi yakni Lembaga Pemasyarakatan. Hal tersebut tercetus pada tanggal 27 April 1964 yang memutuskan bahwa pelaksanaan pidana penjara di Indonesia dilakukan dengan sistem pemasyarakatan, suatu pernyataan yanng menjadi pedoman mengenai arah dan tujuan dalam pembinaan narapidana, sistem ini juga dapat menjadi cara untuk membimbing dan membina narapidana didalam Lapas(Priyatna, 2006).

Lembaga Pemasyarakatan merupakan suatu wadah pembinaan bagi narapidana yang berdasarkan sistem pemasyarakatan bertujuan dan berusaha untuk mewujudkan pemidanaan yang integratif yaitu membina dan kemudian mengembalikan narapidana tersebut kedalam suatu kesatuan hidup masyarakat yang baik dan berguna.

Lapas yang juga sebagai ujung tombak pelaksanaan asas pengayoman merupakan suatu tempat yang didirikan untuk mencapai tujuan sistem pembinaan(Fajriando, 2019) sebagaimana tercantum didalam UU No 12 Tahun 1995 tentang Pemasyarakatan pasal 1 angka 3(Victorio H.Situmorang, 2019). Sebagaimana telah penulis jelaskan sebelumnya dibagian atas, Lapas sesungguhnya merupakan bagian dari suatu sistem peradilan pidana di Indonesia.

Konsepsi struktur hukum (legal structure) menggambarkan suatu sistem peradilan pidana yang mempunyai perangkat struktur atau sub-sistem berupa kepolisian, kejaksaan, peradilan dan Lapas(Victorio H.Situmorang, 2019).

Berdasarkan fakta yang kita ketahui saat ini, sejumlah 33 Kantor Wilayah (Kanwil) Direktorat Jenderal Pemasyarakatan (Ditjen PAS)
Kementerian Hukum dan Hak Asasi Manusia (Kemenkumham), 30 di antaranya mengalami over kapasitas. Hingga tahun 2020, berdasarkan data Napi dan Tahanan yang berada di lapas jambi sejumlah 1175 orang dengan kapasitas yakni 218 orang, hal ini menunjukkan bahwa adanya over kapasitas sejumlah 439\% (Ditjenpas, 2020). Hal ini tentunya mempengaruhi proses pembinaan yang dilakukan oleh Lapas Kelas IIA Jambi saat ini.

\section{Pengertian Sistem Pemasyarakatan}

UU No 12 Tahun 1995 pasal 1 angka 2 menjelaskan bahwa "Sistem Pemasyarakatan adalah suatu tatanan mengenai arah dan batas serta cara pembinaan Warga Binaan Pemasyarakatan agar menyadari kesalahan, memperbaiki diri, dan tidak mengulangi tindak pidana sehingga dapat diterima kembali oleh lingkungan masyarakat, dapat aktif berperan dalam pembangunan, dan dapat hidup secara wajar sebagai warga yang baik dan bertanggung jawab" (Victorio H.Situmorang, 2019). Sistem pemasyarakatan menjelaskan mengenai hak-hak bagi narapidana.

$$
\text { Sebagai negara yang }
$$

berlandaskan hukum seperti Indonesia, hak-hak narapidana dilindungi dan diayomi oleh aparat penegak hukum, terkhususnya petugas di Lapas. Narapidana wajib diberikan dan diayomi hak-haknya walaupun ia telah melakukan perbbuatan melanggar hukum.

Tindakan atau perlakuan apapun yang dilakukan terhadap narapidana, baik berupa pembinaan ataupun tindakan lainnya harusdan wajib bersifat mengayomi dan tidak boleh berlawanan atau bertentangan dengan tujuan sistem pemasyarakatan itu sendiri(Mulyono \& Arief, 2016).

Dengan adanya sistem pemasyarakatan saat ini memberikan makna dan arti yang sangat penting bagi pembangunan sistem hukum pidana bidang pelaksana pidana di Indonesia saat ini. Sistem pemasyarakatan juga merupakan suatu rangkaian kesatuan penegakan hukum 
JURNAL ILMIAH MUQODDIMAH

Jurnal IImu Sosial, Politik, dan Humaniora

pidana di Indonesia. Oleh karena itu, dalam pelaksanaannya tidak dapat dipisahkan pengembangannya terkait konsepsi umum mengenai sistem pemidanaan(Priyatno, 2013).

\section{Pengertian Wali Pemasyarakatan}

Dalam pelaksanaan pembinaan terhadap narapidana yang baru masuk kedalam Lapas, maka narapidana tersebut mendapatkan pendampingan dari Wali Pemasyarakatan. Sebagaimana yang tercantum dalam Permenkumham RI No: M.02.PK.04.10 Tahun $2017 \quad$ Tentang Wali Pemasyarakatan disebutkan bahwa Wali Pemasyarakatan adalah petugas pemasyarakatan yang bertugas untuk melakukan pendampingan terhadap napi dan andik PAS selama mereka menjalani pembinaan di Lembaga Pemasyarakatan.

Kewajiban Wali Pemasyarakatan yakni mencatat identitas napi, latar belakang tindak pidana narapidana, latar belakang kehidupan sosial narapidana, serta menggali potensi Narapidana dan Andik PAS untuk dikembangkan dan diselaraskan dengan program pembinaan yang akan mereka jalani, selain itu kewajuban lainnya ialah memperhatikan, mengamati, mencatat perkembangan pembinaan yang dijalankan, perubahan perilaku yang positif selama di Lapas, hubungan dengan keluarga dan masyarakat sekitarnya, serta ketaatan terhadap tata tertib Lapas dan wali pemasyarakatan juga berkewajiban untuk membuat laporan perkembangan pembinaan narapidana dan perubahan perilakunya sebagaimana dimaksud sebelumnya guna kepentingan sidang TPP (Tim Pengamat Pemasyarakatan) dalam menetapkan program pembinaan yang tepatbagi napi serta lebih lanjutnya.

Selain kewajiban, Wali Pemasyararakatan juga berwenang untuk mengusulkan dalam sidang TPP agar Narapidana dan Anak Didik Pemasyarakatan bisa mendapatkan atau diberikan program pembinaan yang sesuai dengan bakat, minat dan kebutuhan mengenai program pembinaan sesuai dengan tahapan dalam proses pemasyarakatan tersebut, selain itu wali pemasyarakatan juga berwenang menerima keluhan dan melakukan konsultasi jika Narapidana dan Anak Didik Pemasyarakatan mengalami suatu hambatan, baik dalam berinteraksi maupun berkomunikasi dengan sesama penghuni dan petugas maupun dalam mengikuti program pembinaan yang ia jalani. Dalam proses penunjukan tugasnya, wali pemasyarakatan diangkat oleh Kepala Lapas, sehingga dalam pertanggung jawaban tugasnya melakukan pelaporan perkembangan tugasnya kepada Kepala Lapas.

Apabila Wali Pemasyarakatan dianggap lalai dalam melaksanakan tugasnya maka Kepala Lapas dapat memberhentikan tugasnya sebagai Wali Pemasyarakatan. Petunjuk teknis pelaksanaan tugas Wali Pemasyarakatan dalam tugas perwalian terhadap narpi dan andikpas tertera dalam Surat Edaran Direktur Jenderal Pemasyarakatan Nomor : E.PK.04.1090 Tanggal 12 Juli 2007.

\section{Pengertian Admisi Orientasi}

Implementasi pembinaan napi yang dilaksanakan di Lembaga Pemasyarakatan dilakukan secara bertahap dimulai dari sejak penerimaan Narapidana baru kedalam Lapas hingga masa akhir pidananya menjadi anggota masyarakat kembali, termasuk berbagai macam program-program pembinaan yang harus diajalaninya selama ia menjalani masa pidana di Lapas.

Pembinaan terhadap Napi dilakukankan melalui 3 (tiga) tahapan yakni : Tahap awal, tahap lanjutan dan tahap akhir pembinaan. Implementasi pembinaan pada tahap awal dimulai dengan Admisi Orientasi atau biasa disebut MAPENALING (masa pengamatan , penelitian, dan pengenalan lingkungan).

Admisi Orientasi pelaksanaannya diatur dalam dalam Pasal 10 ayat (1) PP Nomor 31 Tahun 1999 tentang Pembinaan dan Pembimbingan Warga Binaan Pemasyarakatan, dijelaskan bahwa 
JURNAL ILMIAH MUQODDIMAH

Jurnal IImu Sosial, Politik, dan Humaniora

pembinaan pada tahap awal diawali dengan Masa pengamatan, pengenalan, dan penelitian lingkungan atau yang dikenal Mapenaling dilaksanakan paling lama selama 1 (satu) bulan semenjak narapidana tersebut masuk kedalam Lapas. Dalam pengalihan setiap tahap pembinaan tersebut dilakukan berdasarkan sidang TPP yang terdiri dari Pembimbing Kemasyarakatan (PK), Petugas PAS dan Wali Pemasyarakatan yang bersangkutan.

\section{Peran Wali Pemasyarakatan dalam pelaksanaan program admisi orientasi bagi narapidana di Lembaga Pemasyarakatan Kelas IIA Jambi}

Pada saat peneliti melaksanakan penelitian mengenai peran wali pemasyarakatan di Lapas Kelas IIA Jambi sejak 10 Juni 2019 s/d 10 Juli 2019 yang dibuktikan dengan terbitnya SK Kalapas Jambi Nomor: W.5.PAS.PAS.1-UM.01.01-348, peneliti menemukan beberapa fakta terkait peran wali pemasyarakatan dalam pelaksanaan program admisi orientasi bagi narapidana di Lapas Kelas IIA Jambi, yakni :

a. Faktor petugas pemasyarakatan yang ditunjuk menjadi Wali Pemasyarakatan.

Dalam melaksanakan perannya sebagai wali pemasyarakatan, ratarata wali pemasyarakatan yang menjalankan perannya belum paham mengenai tugas, tanggung jawab dan kewajiban yang harus dilaksanakannya sebagai wali pemasyarakatan. Fakta tersebut didapatkan penulis melalui wawancara langsung dengan Kasubsi Bimkemaswat Lapas Kelas IIA Jambi (Bapak Dedi Antoni). Beliau mengatakan bahwa :

"kebanyakan wali
pemasyarakatan yang
menjalankan tugasnya hanya
mengerjakan pengisian lembar
kuesioner yang sudah dibagikan
oleh pimpinan, sehingga untuk
perannya secara utuh rata-rata

mereka tidak mengetahuinya(Antoni, 2019)".

Fakta lainnya juga penulis dapatkan dari Bapak Sudomo selaku Staf KPLP Lapas Kelas IIA Jambi yang juga merangkap sebagai Wali Pemasyarakatan, beliau mengatakan bahwa :

"tugas yang saya ketahui sebagai wali pemasyarakatan saat ini hanya sekedar melakukan wawancara terkait identitas, latar belakang keluarga, latar belakang kasus narapidana yang menjadi binaan saya, dan katanya nanti pendampingan yang saya lakukan ini nantinya akan menjadi penilaian dalam sidang TPP nantinya(Supriyono, 2019)".

Terkait dasar peraturan yang menjadi pedoman mereka dalam menjalani tugas sebagai Wali Pemasyarakatan pun tidak diketahui olehnya padahal Permenkumham Nomor : M.01.PK.04.10-90 telah diterbitkan sejak tahun 2007.. Selain itu kurang maksimalnya peran wali pemasyarakatan dalam menjalankan tugasnya dikarenakan adanya rangkap tugas yang mesti dijalani mereka serta keterbatasan waktu yang dimiliki setiap wali pemasyarakatan sehingga program pembinaan tidak berjalan secara maksimal.

b. Faktor Narapidana yang menjalani program Admisi Orientasi

Pelaksanaan program admisi orientasi juga tidak berjalan maskimal dikarenakan narapidana yang menjalani program tersebut tidak mengetahui secara utuh apa tujuan dari dari program admisi orientasi ini. Hal ini diperkuat dengan pernyataan dari narapidana Ahmad yang mengatakan :

"yang sayo tau itu bapak petugas cuma betanyo tentang identitas sayo, latar belakang keluargo dan ekonomi sayo, kronologi kasus sayo bae pak, tapi untuk apo kedepannyo sayo ndak paham jugo pak. Sayo Cuma jawab bae apo yang 
JURNAL ILMIAH MUQODDIMAH

Jurnal IImu Sosial, Politik, dan Humaniora

ditanyokan bapak petugas itu(Ahmad, 2019)".

Jawaban yang serupa pun penulis dapatkan dari 10 orang narapidana yang diwawancarai langsung secara acak. Hal ini tentunya sangat berpengaruh dalam implementasi pembimbingan dalam kegiatan admisi orientasi.

c. Faktor Sarana dan prasarana tempat pelaksanaan program Admisi Orientasi

Hal yang menjadi penghambat dalam pelaksanaan program admisi rientasi juga disebabkan karena kapasitas kamar Mapenaling yang dijadikan tempat pembinaan tidak proporsional sesuai dengan jumlah penghuni saat ini dan kapasitas kamar.

Seharusnya kamar mapenaling hanya berkapasitas 50 orang namun saat ini diisi 205 orang, sehingga berdasarkan penelitian yang dilakukan penulis, hal tersebut juga termasuk dalam beberapa faktor yang turut menjadi kendala dalam pelaksanaan program admisi orientasi bagi narapidana yang ada di Lapas Kelas IIA Jambi.

Selain itu juga terdapat perbandingan yang tidak proporsional antara petugas yang menjadi wali pemasyarakatan dan narapidana yang menjadi binaannya. Saat ini Lapas Jambi hanya memilki 19 orang petugas yang menjadi wali pemasyarakatan sedangkan jumlah narapidana yang menjalani program admisi orientasi sebanyak 205 orang.

Rata-rata setiap wali pemasyarakatan menangani 10-12 orang narapidana. Dengan jumlah narapidana yang lebih banyak daripada jumlah wali pemasyarakatan maka terdapat ketidakseimbangan dalam pelaksanaannya sehingga proses pembinaan tidak berjalan secara maksimal dan tentunya tidak efektif dalam pelaksanaannya..

\section{KESIMPULAN}

Pembinaan dilakukan oleh wali pemasyarakatan kepada narapidana bertujuan agar narapidana tersebut dapat diketahui segala hal ikhwal perihal dirinya termasuk sebab-sebab melakukan tindak pidana, tempat tinggal narapidana, situasi ekonominya, latar belakang pendidikan dan sebagainya.

Wali Pemasyarakatan memiliki tugas yakni mengawasi sikap dan perilaku narapidana serta mengamati perkembangan narapidana serta menilai perkembangannya sebagaimana yang dimaksudkan dalam Permenkumham RI No. M.01 PK.04.10 Tahun 2007 tentang Wali Pemasyarakatan.

Penilaian yang dilakukan berguna sebagai bahan pertimbangan dalam sidang TPP. Wali Pemasyarakatan juga berperan dalam menerima berbagai keluhan dan hal-hal lainya yang berhubungan/ berkaitan dengan narapidana yang dibinanya.

Selama narapidana menjalani masa pembinaannya, pengamatan, pengenalan dan penelitian lingkungan sekitarnya, diadakan sidang TPP yang bertujuan untuk menentukan program maupun strategi pembinaan yang akan diaplikasikan pada tahap selanjutnya.

Putusan dalam sidang TPP harus sesuai dengan hasil pengamatan yang telah dilaksanakan oleh wali pemasyarakatan di Lapas. Secara spesifik penulis dapat menyimpulkan mengenai pengamatan dan hasil pengamatan terkait Wali Pemasyarakatan yakni :

a. Pelaksanaan tugas Wali Pemasyarakatan di Lapas Kelas IIA Jambi sudah berjalan namun belum maksimal dan masih banyak mengalami kekurangan dalam prakteknya dilapangan dikarenakan belum pahamnya mengenai tugas, tanggung jawab dan kewajiban Wali Pemasyaraktan. Dengan adanya Wali Pemasyarakatan dalam mendampingi narapidana telah melakukan pembinaan sesuai dengan perkembangan narapidana selama mereka melaksanakan program pembinaan di Lembaga Pemasyarakatan. Hal tersebut berupa pengamatan dilapangan yakni konsultasi antara narapidana dengan wali pemasyarakatannya 
JURNAL ILMIAH MUQODDIMAH

Jurnal IImu Sosial, Politik, dan Humaniora

b. Wali pemasyarakatan mempunyai tugas dan kesibukan lain disamping sebagai wali pemasyaraktan selain itu wali pemasyarakatan memiliki keterbatasan komptensi dan keterbatasan kemampuan sehinggan narapidana yang menjadi perwaliannya belum spepenuhnya memahami maksud dari program yang diajalani.

c. Dikarenakan proporsional narapidana yang tidak sesuai dengan jumlah petugas yang menjadi Wali Pemasyarakatan, maka program pembinaan terhadap narapidana belum dapat berjalan maksimal.

d. Faktor lain yang menjadi penghambat dalam pelaksanaan program admisi orientasi ialah karena ketidaksesuaian kapasitas kamar dibandingkan dengan jumlah penghuni.

\section{SARAN}

Berdasarkan hasil temuan
penelitian terkait peran Wali pemasyarakatan dalam pelaksanaan program admisi orientasi di Lapas Kelas IIA Jambi, maka penulis memberikan beberapa saran yakni :

a. Mengadakan pengadaan buku saku bagi wali pemasyarakatan agar menjadi pedoman dalam menjalankan tugas sebagai wali pemasyarakatan. Namun meskipun telah adanya buku saku pedoman pelaksanan tugas, kewajiban dan tanggung jawab Wali Pemasyaraktan (Permenkumham RI No. M.01 PK.04.10 Tahun 2007) hendaknya Kalapas secara rutin minimal satu bulan sekali memberikan pengarahan kepada seluruh wali pemasyarakatan agar menjadi pengingat secara lisan.

b. Perlu dilakukan suatu kegiatan pendidikan dan pelatihan secara formal terhadap wali pemasyarakatan agar dapat meningkatkan kompetensi dam kemampuan wali pemasyarakatan dalam melaksanakan tugasnya.

c. Dengan banyaknya jumlah Warga Binaan Pemasyarakatan yang ada di Lapas Kelas IIA Jambi, hendaknya ditambah pula Wali Pemasyarakatan yang memiliki kompetensi dalam melaksanakan tugas sebagai Wali Pemasyarakatan

d. Perlu adanya penambahan kamar mapenaling agar kegiatan program admisi orientasi berjalan efektif.

\section{DAFTAR PUSTAKA}

Ahmad. (2019). Wawancara Langsung. Antoni, D. (2019). Wawancara Langsung.

Aryana, I. W. P. S. (2015). Efektivitas Pidana Penjara Dalam Membina Narapidana. Jurnal IImu Hukum, 11(21), 39-44.

Dewi, V. N. S. (2016). Pelaksanaan Pembinaan Narapidana Di Lembaga Pemasyarakatan Kelas IIA A Wirogunan(Studi Kasus Mary Jane). Pelaksanaan Pembinaan Narapidana Di Lembaga Pemasyarakatan Kelas IIA A Wirogunan(Studi Kasus Mary Jane). https://doi.org/10.1088/17518113/44/8/085201

Ditjenpas. (2020). Sistem Database Pemasyarakatan.

Fajriando, H. (2019). Evaluasi Pelaksanaan Community-Based Corrections di Lapas Terbuka Kelas III Rumbai. Jurnal IImiah Kebijakan Hukum, 13(3), 323. https://doi.org/10.30641/kebijakan. 2019.v13.323-338

Hadikusuma, H. (1995). Metode Pembuatan Skripsi IImu Hukum. Bandar Maju.

Haryono, H. (2018). Optimalisasi Pelaksanaan Tugas dan Fungsi Lapas Terbuka dalam Proses Asimilasi Narapidana. Jurnal IImiah Kebijakan Hukum, 12(3), 295. https://doi.org/10.30641/kebijakan. 2018.v12.295-311

Kementerian Hukum dan Hak Asasi Manusia. (1995). Undang-Undang Republik Indonesia Nomor 12 Tahun 1995 Tentang Pemasyarakatan. 1-22. Moleong, L. J. (2000). Metodologi 
JURNAL ILMIAH MUQODDIMAH

Jurnal IImu Sosial, Politik, dan Humaniora

Penelitian Kualitatif (18th ed).

Remaja Rosdakarya.

Mosgan Situmorang. (2016). Aspek

Hukum Pemberian Remisi Kepada

Narapidana Korupsi. Jurnal

Penelitian Hukum, 16(740), 375394.

Muhammad, A. (2004). Hukum dan

Penelitian Hukum. PT Citra Adytia Bakti.

Mulyono, G. P., \& Arief, B. N. (2016).

Upaya Mengurangi Kepadatan

Narapidana Dalam Lembaga

Pemasyarakatan Di Indonesia. Law

Reform, 12(1), 1.

https://doi.org/10.14710/Ir.v12i1.15

838

Priyatna, D. (2006). Sistem

Pelaksanaan Pidana Penjara Di

Indonesia. PT Refika Aditama.

Priyatno, D. (2013). Sistem Pelaksaan

Pidana Penjara di Indonesia.

Refika Aditama.

Supriyono. (2019). Wawancara Langsung.

Victorio H.Situmorang. (2019). Lembaga pemasyrakatan sebagai bagian dari penegakan hukum

(Correctional Institution as Part of Law Enforcement). Jurnal IImiah Kebijakan Hukum, 13(1), 85-98.

Yopi Gunawan and Kristian. (2015). Perkembangan Konsep Negara Hukum Dan Negara Hukum Pancasila (Cetakan I). Refika Aditama. 